\title{
Influence of Preheating and Heat Treatment after Welding According to the EN 13445 and ASME Code on the Hardness Level of Welded Joints for the Pressure Vessel Plates
}

Libor Beneš ${ }^{1}$, Tomas Kolegar ${ }^{1}$, Martin Tojmar ${ }^{2}$, Petr Majrich ${ }^{3}$

Czech Technical University, Faculty of Mechanical Engineering, Department of Material Engineering

Email: ${ }^{1}$ libor.benes@fs.cvut.cz; ${ }^{1}$ tomas.kolegar@fs.cvut.cz; ${ }^{2}$ martin.tojmar@bronswerk.cz; ${ }^{3}$ petr.majrich@fvtm.ujep.cz

The paper deals with an analysis of preheating and heat treatment after welding and their influence on the final hardness level in case of welded jonits for common materials applied for manufacture of pressure vessel plates. During the welding process, the higher values of hardness and simultaneously decreasing of plasticity was observed and measured in the heat affected zone. Therefore, there was necessary to preheat the base material, or to apply the heat treatment after welding, or to suggest any combination of both mentioned ways. First of all, the groups of tested plates with required parameters were chosen for the application of the submerged arc welding method (according to ČSN EN ISO 4063), and preparation of samples for hardness measurement (ČSN EN ISO 6507) as the next step. The main goal of this experiment was to determine the hardness level for two fine grained steel grades after welding with the given parameters, as well as to adjust or to eliminiate the heat treatment process (preheating, post-heating), if they are not necessary.

Keywords: welding, heat treatment (pre-heating, post-heating), hardness level, EN 13445, ASME Code

\section{Acknowledgments}

This work was supported by the Ministry of Education, Youth and Sport of the Czech Republic, programm NPU1, project No. LO1207 and the SGS research project CTU in Prague, No. 161-1611360B001.

\section{References}

[1] TEAM OF AUTORS. Company documentation of Bronswerk Heat Transfer spol. s.r.o., Benešov nad Ploučnicí

[2] TEAM OF AUTORS (1991). ASM Handbook, Vol. 4 - Heat treating, USA, 2173 p.

[3] TEAM OF AUTORS (1993). ASM Handbook, Vol. 6 - Welding, Brazing and Soldering, USA, 2873 p.

[4] KOLEGAR, T. (2014). Influence of preheating before welding and heat treatment after welding according to EN 13445 and ASME Code for hardness of weld, Diploma thesis, UJEP - FVTM, 98 pp., 2014.

[5] PTÁČEK, L. (2002). Material Science I., Academical publishing house CERM, s.r.o., Brno, 516 p.

[6] PTÁČEK, L. (2003). Material Science II., Academical publishing house CERM, s.r.o., Brno, 392 p.

[7] PERIK, J., SOLC, M., MIKLOS, V. (2014). Applied Load and Calibration of the Hardness Tester - Manufacturing Technology. Vol. 14, pp $228-234$.

[8] NOVÁK, M. (2011)). Surface quality of hardened steels after grinding. Manufacturing Technology, Vol. 11, pp. 55-59, ISBN 1213-2489.

[9] MÁDL, J. (2012). Surface Properties in Precise and Hard Machining. Manufacturing Technology, Vol. 12, pp. 158-166. ISSN 1213-2489.

[10] VRZGULA, P., FATURÍK, M., MIČIAN, M. (2014). New Inspection Technologies for Identification of Failure in the Materials and Welded Joints for Area of Gas Industry. Manufacturing Technology, Vol. 14, pp $487-492$. ISSN 1213-2489.

[11] KOLAŘÍKOVÁ, M., KOLAŘÍK, L., KOVANDA, K., HRANINA, R. (2013) Welding of Normalized Heat Treated Steels S355NL Large Thicknesses by Method FCAW. Manufacturing Technology, Vol. 13, pp 181 - 188. ISSN 1213-2489.

[12] KALINCOVÁ, D. (2012) Analysis of welded joints of band-saw blade - influence of annealing process on joint microstructure and mechanical properties. Manufacturing Technology, Vol. 12, pp 125 - 131. ISSN 1213-2489. 